Article

\title{
Reducing Energy Subsidies in China, India and Russia: Dilemmas for Decision Makers
}

\section{Grant Dansie ${ }^{1}$, Marc Lanteigne ${ }^{2}$ and Indra Overland ${ }^{1,3, *}$}

1 Norwegian Institute of International Affairs (NUPI), PB 8159 Dep., 0033 Oslo, Norway;

E-Mail: grant.dansie@nupi.no

2 University of St. Andrews, St. Andrews, Fife KY16 9AJ, Scotland, UK;

E-Mail: ml80@st-andrews.ac.uk

3 University of Tromso, 9037 Tromso, Norway

* Author to whom correspondence should be addressed; E-Mail: ino@nupi.no; Tel.: +47-22-99-40-51; Fax: +47-22-36-21-82.

Received: 18 December 2009 / Accepted: 26 January 2010 / Published: 1 February 2010

\begin{abstract}
This article examines and compares efforts to reduce energy subsidies in China, India and Russia. Despite dissimilarities in forms of governance, these three states have followed surprisingly similar patterns in reducing energy subsidies, characterised by two steps forward, one step back. Non-democratic governments and energy importers might be expected to be more likely to halt subsidies. In fact, the degree of democracy and status as net energy exporters or importers does not seem to significantly affect these countries' capacity to reduce subsidies, as far as can be judged from the data in this article. Politicians in all three fear that taking unpopular decisions may provoke social unrest.
\end{abstract}

Keywords: energy subsidies; politics; China; India; Russia

\section{Introduction}

More than half of the world's states subsidise energy in some form. Globally, energy subsidies amounted to USD 220 billion per year, or approximately 0.7 percent of world GDP in 2006 [1]. Since most subsidisers are in emerging economies, the problem of energy subsidies has a major impact on efforts to eradicate poverty and pollution in some of the world's most important developing countries. Energy subsidies distort economies, encourage inefficiencies and contribute to the production of 
greenhouse gases. Why then is it so difficult to remove them? This article examines the key obstacles to reducing energy subsidies in China, India and Russia.

We focus on these three states both because of what they represent collectively and because of the contrasts among them. These countries are all among the top five in subsidy spending, and thus represent a large part of the world's energy subsidies. All three have experienced significant economic growth in the past decade accompanied by corresponding increases in energy demand, and this is projected to continue. Due to their rapid development, these states also have the potential to serve as growth models for poorer developing countries, so their energy policy choices have implications for many other governments.

Furthermore, these three countries are interesting to compare because of the differences among them. Whereas China and India are two of the largest energy importers, Russia is the world's largest exporter of energy [2]. Income levels vary widely in the three, here stated in terms of GNI per capita/USD/PPP: India 2,740 - China 5,370-Russia 14,400 [3]. Politically they are also strung out on a scale from democratic to authoritarian. Whereas India is considered the world's largest democracy, Russia is seen to have a semi-authoritarian or a hybrid regime, and China remains a oneparty state, albeit with a government that is becoming increasingly decentralised (for more on the concept of hybrid regimes and semi-authoritarianism, see Diamond [4] and Schedler [5]).

Politicians face considerable dilemmas in dealing with energy subsidies. One might expect that democracies would have a more difficult time abolishing subsidies than would non-democratic governments. After all, democratic politicians need to maintain their popularity to stay in office, so they should be loath to remove subsidies that might have the short-term effect of making their constituents' lives more difficult. By contrast, authoritarian leaders are in theory more isolated from such pressures and should be able to act in the country's rational economic interest. Likewise, one would expect energy importers to have an easier time removing subsidies, for the simple reason that, with high energy costs, they simply cannot afford to maintain such payments to the population. Conversely, energy exporters, flush with cash, should be better placed to continue energy subsidies for their populations.

In fact, the findings of the research conducted for this article, although not conclusive, indicate that neither of these expectations holds up in the three countries examined. Once subsidies are in place, governments of all kinds have difficulty removing them. The article proceeds by first defining subsidies and analysing the arguments for and against them. Then it examines the experience of China, India and Russia, emphasising the halting progress that each has made in trying to remove subsidies. Analysis shows that in all three examples politicians fear offending powerful constituencies that benefit from the subsidies. Given this real-world outcome, we conclude that democratic India may ultimately in fact have a slight advantage over the other two countries in tackling the problem of energy subsidies.

\section{Arguments for and against Subsidies}

In a budgetary context, subsidies may be defined as 'unrecovered costs in the public provision of private goods' [6]. Whereas the most visible form of subsidy is a direct, untargeted price subsidy, many other forms exist. Untargeted indirect price subsidies, including exemptions on value-added or 
other sales taxes, dual exchange rates, export taxes, producer quotas, subsidies on transport and storage, and domestic sales of a commodity below international opportunity cost are all forms of subsidisation [7]. Furthermore, a given commodity may be cross-subsidised, meaning that some consumers are charged a price above cost so as to finance a price below cost for other consumers [6]. For example, in terms of electricity consumption, commercial consumers may pay a price well above cost in order to finance a subsidy on electricity for agricultural users. Although subsidies are, in one sense, economic phenomena, in other respects they are political - the result of politically-determined efforts to compensate for market failure, to help the poor or to accelerate development.

Governments commonly cite two main justifications for energy subsidies. First, they use them to promote overall economic development. This includes stimulating fledgling economic sectors and thus speeding up industrialisation, increasing the mobility of goods and the workforce and improving the working conditions for welfare institutions dependent on energy supplies (hospitals, schools, water processing etc.) [8]. Second, subsidies are often intended to benefit the poorer members of the population in particular, through the employment opportunities that result from accelerated development and from subsidies specifically targeted at the forms of energy used by the poor.

Despite the potential short-term beneficial effects of subsidies, there are also important reasons to reduce or remove them. Firstly, as long as prices remain artificially low, energy conservation will be less attractive to consumers and climate gas emissions will be unnecessarily high. An OECD study has shown that global carbon dioxide emissions could be reduced by more than 6 percent between 2000 and 2010 if all subsidies for fossil fuels used in industry and the power sector were removed worldwide [1]. Most of the future increase in energy demand and emissions will come from China and India and major petroleum-exporting countries such as Russia $[9,10]$.

Secondly, subsidies are a burden on government budgets, especially with high prices for energy on world markets. Although oil prices have been volatile for the last four years, the past decade has shown a rising trend, and the prices of other energy carriers are correlated with the oil price. The global recession starting in late 2008 brought about somewhat lower oil prices, but it has actually worsened the burden for subsidising states, as falling tax revenues make it even harder to sustain subsidy levels. This is a significant problem in many developing countries, as increased relative spending on subsidies detracts from other priorities, including education, healthcare and infrastructure. There is also the issue of rent-seeking behaviour: subsidy regimes can encourage policymakers to manipulate subsidy rules for individual rather than collective gain.

Third, higher energy consumption promoted by energy subsidies forces energy importers to step up their imports as domestic reserves dwindle, thus aggravating the threat to energy security from external supply disruptions, and at the same time increasing friction with other importing countries. China's and India's subsidy-driven, rising imports of energy have led to greater competition and occasional friction with old major energy importers such as the European Union and the US in African and Latin American petroleum-exporting countries [11].

Fourth, underpricing of energy results in sub-optimal investment decisions regarding type and placement of capital equipment and infrastructure in the energy sector.

Fifth, subsidies provide significant market barriers to the development of renewable energy, which cannot compete against artificially low prices for fossil fuels and nuclear power. This also affects areas such as investment, competition and compliance with international trading laws. In addition, the vast 
sums spent on subsidies limit the amount of capital available for investment in renewable energy. Finally, the high energy consumption promoted by energy subsidies can also result in severe environmental problems at the local level. For example, in parts of China, emissions from coal used to generate electricity and diesel used for trucking have significantly reduced standards of living and life expectancy [12].

In sum, at the economic and environmental levels there are more weighty reasons to remove energy subsidies than there are arguments for keeping them in place. On the other hand, their removal also involves significant political dilemmas for decision makers in low and middle-income countries, as it may generate political discontent among the former beneficiaries of energy subsidies.

\section{China}

\subsection{Energy Overview}

In the space of a generation, China has evolved from a minor and largely self-sufficient energy consumer to the world's second-largest and fastest growing energy importer [13,14]. The country has been seeking to undertake what one study calls an 'energy transition': the shift from low-quality solid fuels like coal to liquid fuel and electricity, and from heavy to light and high-technology industries [15]. Nevertheless, coal remains the foundation of the Chinese energy system, covering close to 70 percent of the country's primary energy needs and representing 80 percent of the fuel used in electricity generation. Coal has grown rapidly in importance in recent years along with the rising demand for electricity. Oil demand has likewise grown quickly, both before and after China became a net oil importer in 1993 [16]. Contributing to the country's vulnerability to the instability of the global oil market is the explosion in automobile ownership, expected to reach 387 million vehicles by 2030, well above American levels [17]. The World Bank and the country's then-State Environmental Protection Agency (SEPA) estimated that outdoor pollution, caused largely by the burning of coal and diesel, causes from 350,000 to 400,000 premature deaths a year, mostly among women and children [18]. All of this can be linked to the trend of increasing energy consumption driven by the combination of fast-paced economic growth and energy subsidies.

Energy policymaking in China is largely decentralised. There has been no Ministry of Energy since it was dissolved in 1993, and it was only in 2002-2003 that serious governmental dialogue on re-centralising energy administration began [16]. At present, the establishment of an energy ministry would have to take into account the interests of various powerful institutions, companies and actors, involving considerable bureaucratic conflict — as was demonstrated by the failure to reach an agreement in this area at the 17th National Congress of the Communist Party in October 2007 [19]. Currently, China's energy industries are governed by a farrago of ministries and commissions, and companies with varying levels of power and influence, such as the Chinese National Petroleum Corporation (CNPC) and the China Petroleum and Chemical Corporation (Sinopec). Both of these companies originally comprised one ministry before being converted to state companies in the 1980s. They have retained the same hierarchical rank as government ministries, putting them higher than the sub-ministerial bureau charged with supervising them [20]. These complicated organisational 
structures and interrelationships complicate any efforts to change the way energy is priced and billed. As we will see in the sections on India and Russia, this is not unique to China.

\subsection{Subsidy Policies}

Although it is difficult to measure Chinese energy subsidies, the country oversaw about USD 26 billion worth of subsidies in 2005, according to the International Energy Agency, making it the third largest subsidiser in the world (in nominal terms, not per capita) [21]. China's communist system once provided widespread subsidies, but now prices are approaching world levels. While price guidelines in China are set by the National Development Research Council (NDRC), the country's top economic planning agency, actual costs and subsidies vary across China as prices are influenced by local regulators [20]. A 2007 governmental White Paper acknowledged that 'China's energy market system is yet to be completed, as the energy pricing mechanism fails to fully reflect the scarcity of resources, its supply and demand, and the environmental cost' [22].

China has the second-largest electricity market in the world after the United States, but with per capita energy consumption less than one-fifth of the OECD average [14]. Yet, the Chinese electrification scheme has been a massive success-and contributed significantly to poverty reduction [14,23]. In 2005 alone, China added 66 gigawatts of generation capacity to its power grid, and in 2008 it added an additional $102 \mathrm{GW}$, an increase credited entirely to small- and medium-sized coal-powered plants [18]. The NDR sets electricity tariffs on a province-by-province basis on the recommendations of local bureaus that answer to local officials. The NDRC has attempted to standardise energy pricing and reduce overall energy consumption, but these efforts are often hindered by local social and economic concerns. Electricity has long been underpriced and subsidised, and local officials are often able to renegotiate special arrangements for their constituencies [20]. Despite this, the country's greater immersion into global energy markets has led to the linking of electricity prices to the cost of coal and consumption, with the introduction of more transparent pricing mechanisms. The current situation is one of two-tier tariff rates to reduce electricity consumption by energy-intensive industries, while retail electricity prices have also risen to reflect higher coal prices [19].

China consumes more coal than the USA, the EU and Japan combined [17,18]. Electricity is four-fifths coal-based, with electricity demand booming. Beijing has now begun importing coal in larger amounts, reaching a high of net imports of 22 million tonnes between January and May 2009 [14,24]. Prior to 1993, coal prices were set by the Ministry of Coal and the State Planning Commission, but since then prices have gradually become more market-based. However, with electricity price controls still in place, steam or power coal prices are still often set below cost, with little price visibility [14]. During the summer of 2008, energy demand prompted Beijing to request that coal mines maintain full processing capacity, even calling for the re-opening of smaller mines previously shut down due to safety concerns. At the same time, two provinces, Shaanxi and Shandong in east-central China, broke with Beijing and introduced their own price caps in order to avoid social discontent, despite concerns that such artificial pricing schemes would only exacerbate existing supply problems [25]. This illustrates the challenges of changing the pricing and billing of energy related to 
the complex relationships between central and regional authorities. We shall see that this is the case not only in China but also in India and Russia.

As regards oil, in theory China pegs domestic prices for petroleum products via a weighting system linked to prices set in Singapore, Rotterdam and New York, but in reality Beijing has been reluctant to adjust prices in the wake of rising oil costs out of concern for the fragility of its domestic economy [17]. The method of subsidisation is through control of refinery gate prices, thus squeezing refiners' margins. The goal of the Chinese pricing control system is to ensure affordable access to oil products for those actors most in need, in order to mitigate discontent amidst the country's rapid growth. Thus, oil and derived product subsidies target end-users such as farmers, truckers, fishermen and motorists rather than industrial users. For these groups, prices are 15-20 percent below market levels for oil products, contributing to significant growth in demand [26]. Oil is China's second-most subsidised energy commodity after coal [27].

\subsection{Subsidy and Pricing Reform Efforts}

Despite an increasingly liberal approach to economic policy, Beijing has approached energy market reform conservatively, regarding energy as a key strategic commodity while still seeking to adjust to global market conditions. Following thirty years of gradual convergence with world prices, progress has accelerated since 2005. The IEA estimates that subsidies (after taxes) fell 58 percent from 2005 to 2006, to a total of USD 11 billion. Nominal subsidies on oil products and coal have fallen sharply, but some subsidies on household heating and cooking fuels remain in place. In percentage terms, under-pricing is greatest for natural gas and coking coal [14]. One of the main reforms contained in the 11th Five-Year Plan concerns the system of energy pricing and taxation. This will involve a further upward adjustment of oil and natural gas prices, along with subsidies for renewable energy. In December 2008, China revealed plans to revamp its oil pricing system, combining a big increase in fuel taxes for consumers with the first steps in liberalising prices for petrol and diesel. By 2009, Beijing began to exploit the sharp recessionary decline in oil prices to begin long-overdue reform of a pricing structure that has left Chinese refineries vulnerable to movements in global markets. This includes a plan to raise the number of strategic petroleum reserve bases from four to twelve by $2011[28,29]$.

Coal subsidies have been significant, and international observers voiced concern when a US report surfaced in January 2008 revealing that Beijing had provided USD 15.7 billion in energy subsidies specifically for the Chinese steel industry in 2007 (an increase of 3,800\% since 2000) [30]. As fuel prices continue to be set by the state, and the actual subsidy regime remains opaque, many Chinese consumers have been shielded from the spike in global prices since the middle of the decade. However, in June 2008, Beijing announced a price rise of 16 percent for petrol and 18 percent for diesel oil, and average petrol prices jumped to about USD 0.85 per litre. That was still well below average 2008 high-tax EU rates, but on a par with prices in the US. In addition, electricity prices increased as of July 2008 by an average of RMB 0.025 (USD 0.004) per kilowatt hour. The effects of these increases were unevenly distributed, however, as Beijing also announced a series of side-subsidies totalling about USD 2.9 billion to relieve the additional financial burden on grain farmers, taxi drivers and lower-income persons, all in the hope of staving off popular unrest. Such sweeping increases had not 
been expected to take place until after the August 2008 Beijing Olympic Games, but strains caused by international prices, inflationary pressures as well as fuel shortages in the country probably prompted the government's decision not to bring forward the price hike [31,32]. There have also been calls for a more equitable distribution of subsidies - including a recommendation in 2006 by the head of the Chinese Central Bank for a removal of subsidies but more support for the services sectors in China, which are comparatively more energy efficient and environmentally friendly than manufacturing [33].

Since January 2009, Chinese consumers have been paying higher fuel taxes; petrol has risen fivefold to RMB 1 (USD 0.12) per litre and diesel from RMB $0.1-0.8$ a litre. However, the government has stated that these higher taxes will replace six different fees paid by consumers, including road tolls. Consumer prices will reportedly not rise as a result of the new reform, which suggests that the headline retail price will be lowered significantly when the new system is introduced. Since the start of 2009 there has been a new pricing plan in place. There came a series of price increases on fuels, including a 9-10 percent jump in petrol and diesel rates announced in June, but even at that there do not appear to be strong signs that driving habits are being curtailed as a result of the reforms $[34,35]$.

\section{India}

\subsection{Energy Overview}

India is currently the world's sixth-largest consumer of energy, accounting for approximately 3.6 percent of world energy consumption by 2006 [36]. As in the case of China, the Indian energy sector is dominated by coal, which accounted for 39 percent of total primary energy demand in 2005 and currently accounts for nearly 70 percent of electricity generation. India is the third-largest user of coal products (as a country rather than per capita) after China and the United States, producing 88 percent of its own coal needs. This means that Indian energy consumption is a significant factor in global climate gas emissions.

Energy demand has been increasing in recent years in tandem with India's emergence as a global economic player and continuing subsidies. It averaged an annual 3.2 percent growth in 2000-2005. Although the International Energy Agency predicts that primary energy demand will double by 2030 [14], at present per capita energy demand is extremely low. With 17 percent of the world's population, India accounts for only 5 percent of world energy demand-which may explain the Indian government's reluctance to commit to greenhouse gas emission caps. The country imports much of its energy, including 70 percent of its oil in 2005, equivalent to approximately 3 percent of world oil supply. This means that India's subsidy-fuelled energy consumption is contributing to energy insecurity in terms of an increased risk of external supply disruptions.

Improving access to energy is a major issue in India: approximately one-third of the world's population without access to electricity live in India, and about 40 percent of the people lack access to modern energy [37]. This makes it particularly difficult to remove subsidies, insofar as such a move is perceived to reduce access to energy.

In terms of governance, responsibilities are divided between the central government and state governments. At the central government level, policymaking and implementation in the energy sector 
is divided between five different ministries and several government commissions and agencies. State governments have significant responsibilities in the energy sector, especially in the area of electricity. Indeed, the Indian Parliament is barred from the legislation of certain aspects of the power sector. For the most part, however, the local state authorities are responsible for implementing national laws, but may also pass state laws and regulations for application in their own state [14]. Key state-level agencies include the State Electricity Boards (SEBs) and the State Electricity Regulatory Commissions (SERCs). The SEBs are responsible for the majority of generation and virtually all transmission and distribution, while the SERCs oversee the setting of tariffs for public utilities and private companies [38]. Even more than in China, we see that the federal structure of the state and the division of powers between central and regional authorities is bound to be a complicated factor in any efforts to change energy subsidies and pricing.

\subsection{Subsidy Policies}

In total, the Indian government spends approximately USD 19 billion on energy subsidies annually [1]. Even for a country as large as India, this figure is significant as it equates to USD 17 per person - a considerable figure in view of the fact that an estimated 456 million Indians subsist on under USD 1.25 a day [3]. Pachauri and Jiang estimate that energy expenditure in urban areas was approximately 2.5 percent of the total household budget, while it was double that for rural households [39]. Electricity subsidies in India have been substantial, approximately USD 9 billion annually [14].

Energy subsidies have long been a favourite tool of Indian politicians seeking to win favour in the next round of elections. An important characteristic of these subsidies is the significant disparity in prices paid by end-users due to cross-subsidisation. The rate of subsidy using 1999-2000 cost data represents 93 percent of the total cost of electricity for agriculture and 58 percent for households [40]. Despite the high cost, state governments have hesitated to reduce subsidies because of the significant political power held by those with interests in maintaining current subsidy rates, especially farmers and other rural interests [38].

India subsidises fuels in a variety of ways. Kerosene and liquid petroleum gas (LPG) are subsidised directly, while other fuels such as diesel are kept artificially inexpensive by preventing price hikes by the state oil companies. These companies are kept afloat with so-called oil bonds guaranteed by the government, a situation which one rating agency noted was distorting prices and passing costs on to future generations [40]. Thus, in terms of setting prices and subsidy rates, the central government controls the cost of kerosene, LPG and diesel fuels, whereas the individual states control electricity prices.

Cross-subsidies are an important feature of the Indian energy sector. The overarching logic of cross-subsidisation is to use petrol and aviation turbine fuel, used by the relatively rich, to subsidise kerosene, cooking gas and fuels for fertiliser production and distribution, i.e., products meant for the vulnerable sections of society [6]. By charging some consumers a price higher than cost, governments can provide fuel to other consumers below cost. Since the energy sector is largely state-owned, the Indian government has historically played a central role in setting energy prices and subsidising various energy sectors. On the national level, interventionist policy was carried out through the 
administered price mechanism (APM) which controlled the prices of petroleum products, while at the state level the SEBs set electricity tariffs, although their flexibility was heavily constrained by state governments [6].

\subsection{Subsidy and Pricing Reform Efforts}

During the 1990s, following an economic crisis, the Indian government began a series of reforms in the energy sector. This included removing trade restrictions and opening up the energy sector to private and foreign investment, in some cases privatisation [40]. In addition, New Delhi officially abolished the administered price mechanism in 2002 for all petroleum products except kerosene and LPG. Price controls on petrol and diesel were subsequently re-imposed [14]. Other energy sector reforms have proceeded very slowly [37]. Kale outlines a number of reasons for this: the balance of social and political power both within states and nationally, changes in the global ideology of electricity supplies towards liberalisation, and the strength of rural interests and labour unions [38]. Nevertheless, there are signs that New Delhi is seeking further adjustments, as evidenced by the government's June 2008 Economic Survey which called for reform of petroleum and fertiliser subsidies, including restricting subsidies for domestic cooking gas to 6-8 cylinders per year [41].

\section{Russia}

\subsection{Energy Overview}

Russia is one of the world's energy powerhouses. It holds the world's largest natural gas reserves ( $27 \%$ of total), the second-largest coal reserves, and the eighth-largest oil reserves. Russia is the world's largest exporter of natural gas, the second largest oil exporter, and the third largest energy consumer [27,42]. Natural gas makes up the core of the country's energy stockpile, providing 52.8 percent of total primary energy supply in 2006 [27].

In 2003, energy consumption per dollar of purchasing power parity GDP was estimated to be 2.3 times the world average and 3.1 times the European average [42]. However, an estimated 45 percent of all Russian energy is lost in production, transport, transmission or inefficient consumption-much of this due to artificially low prices which reduce incentives to improve efficiency [43]. According to several estimates, Russia could save around half of the energy it currently uses, equal to the annual primary energy consumption of France [42,43].

\subsection{Subsidy Policies}

According to the World Bank, Russian energy subsidies are the largest of any country in the world, totalling USD 40 billion in 2005 [43]. Approximately USD 25 billion of these subsidies go to natural gas, with the remainder spent on electricity (including under-pricing of gas delivered to power stations) [21].

Moscow's involvement in the energy sector has significantly increased in recent years. Pricing is divided between different levels of government and defined by sector and commodity. The Federal 
Tariff Service sets gas and wholesale electricity prices, the Regional Energy Commissions set co-generated electricity and heating prices, and municipalities set prices for heat transmission and heat generation by municipal boilers. Heavily subsidised district heating - the distribution of heat from a central locale to subsidiary commercial or residential areas - plays a major role, providing over a third of energy requirements for industry and close to half those of the commercial and household sectors. Almost 50 percent of primary energy consumption in Russia is used for heat generation, transmission and distribution [44]. In 2002, total budget allocations for heat ranged from USD 3.5 billion to USD 4 billion, of which around USD 2 billion were subsidies in the form of payments to heat suppliers and low-income families. The government also offers interest-free loans for the supply of fuel to district heating companies in remote locations.

Gazprom, which was responsible for 85 percent of gas production in 2007 and accounted for approximately 25 percent of federal tax revenues, is required by law to supply the natural gas used to heat and power Russia's vast domestic market at government-regulated prices, regardless of profitability [2]. As Ahrend and Thomson note, the Russian gas sector has been highly resistant to liberalisation, and 'the domestic gas market is a market in name only. It is in reality a rationing mechanism with market-based activity at the fringes' [42].

Domestic gas prices generally are barely 15-20 percent of the market rate at which Russia's gas is sold to Germany, resulting in Gazprom losing approximately USD 42 billion in 2006 on domestic natural gas sales [42]. The rate of subsidy varies according to the distance from the wellhead, and is further differentiated into household and industrial tariffs. In 2004, household tariffs ranged from 65 percent to 88 percent of the industrial tariff, depending on region. These subsidised tariffs have affected the gas industry's ability to finance infrastructure maintenance and expansion, as well as curbing incentives to increase efficiency [27]. According to the IEA, the sums spent by Russia on natural gas subsidies are twice as large as the annual investment needed for the country's entire gas industry [21].

Electricity prices have been extensively subsidised in Russia, although these subsidies will decrease gradually as prices continue to rise as a result of electricity sector reform. The IEA noted in 2006 that wholesale electricity prices would need to rise an additional 40 percent before becoming cost effective, and electricity subsidies totalled USD 15 billion that year [21]. Despite Russia's status as a major producer and exporter of energy, it is estimated that approximately five million farms and ten million Russians are not connected to the major grids [45].

\subsection{Subsidy and Pricing Reform Efforts}

Moscow has announced a plan to gradually increase domestic gas and electricity prices. The official target, although frequently adjusted, has been to achieve parity with international market prices for the Russian industrial sector in 2011 and for households a few years later. However, this process has been hampered by the country's struggle with the global recession. Recent energy reforms include the 2008 dissolution of the Russian electricity monopoly RAO-UES, with tariff rates partially levelled out across the country. In 2006, the generating sector was divided into multiple wholesale electricity companies (OGKS), which participate in a new competitive wholesale market. Furthermore, 14 territorial generating companies (TGKs-territorialnye generiruyushchie kompanii) 
were created, generating over USD 24 billion in private investments in 2007 [46,47]. Yet Russia's transmission grid will remain under state control, as in most countries [48]. The government sees electricity sector reform as essential to reduce domestic natural gas consumption.

Furthermore, Russia has gradually increased gas and electricity prices during the past few years [49]. On average, electricity tariffs increased by approximately 240 percent between 2005 and 2009, although inflation, at about 12 percent per year, has also softened the price hike. While the Russian electricity sector was for a long time cross-subsidised with residential prices lower than industrial prices, the phasing out of cross-subsidies saw average increases from approximately 60 percent of industrial tariffs in 2000 to near-parity in 2004 [50].

\subsection{A Common Pattern: Two Steps Forward, One Back}

Despite the differences in political systems and their status as energy importers or exporters, China, India, and Russia show remarkable consistency in their energy subsidy policies. While all three countries have greatly reduced the energy subsidies that they provide to their population, they have not been able to end subsidies entirely.

Even when governments do make the painful decision to reduce or end subsidies, real implementation of subsidy reform policies is not a given. All three countries share a pattern of two steps forward, one step backward on subsidy reform. Or perhaps more precisely, it is a pattern of two steps forward and then a pause before moving on. For example, China has been successful in extending grid connection to 99 percent of the population, while decreasing subsidies by an impressive 58 percent between 2005 and 2006 [14]. Russia increased average electricity prices by approximately 240 percent between 2000 and 2004, with residential tariffs increasing by approximately 340 percent, and industrial tariffs 200 percent. These are both examples of big steps forward.

Despite these gains, reform efforts have only been partially implemented and, in some cases, rolled back. Although China's greater immersion into global energy markets has led to the linking of electricity prices to the cost of coal and consumption, the current situation is one of two-tier tariff rates to reduce electricity consumption by energy-intensive industries, while the household sector remains more heavily subsidized [19]. While Russia has made some progress in reducing subsidies for natural gas, politicians have repeatedly revised targets downwards, especially before elections. After removing price controls, New Delhi was forced to re-impose them to protect consumers after rapid oil price increases during mid-2008, another example of a step back.

\section{Why Is Removing Energy Subsidies So Difficult?}

Despite the differences between China, India and Russia in terms of political system and energy endowment, the issue of subsidy reform has major social and political significance for all of them. Politicians in all three countries have been wary of provoking social unrest by imposing unpopular energy price hikes. This problem is not more acute for democratic India, where one would expect to see such problems, than it is for non-democratic Russia and China. 
Nor does it matter whether a country is an energy exporter or importer. While one might expect to find energy subsidies in Russia, where energy supplies are abundant, net importers China and India have been operating large subsidy programmes as well.

While all three countries have announced their commitment to subsidy reform, in all three cases the biggest barrier to reducing subsidies is the powerful constituencies that benefit significantly from the current subsidy regimes, and thus have a sustained interest in maintaining the status quo. These interests vary from country to country: farmers and the urban middle class in India; truckers, farmers, fishermen and car owners in China; energy-intensive industries and domestic consumers of gas and district heating in Russia. These groups represent powerful constraints on state policy, regardless of whether the state in question is democratic or not.

While the fractious nature of Indian politics logically creates a poor basis for large-scale subsidy reform in India, why are the authoritarian and semi-authoritarian regimes in China and Russia unable make more progress? The answer may lie in the implicit social contracts that help sustain these regimes. The people of China and Russia tolerate and accept reduced social freedoms, provided their governments ensure stability, growth and increasing real incomes and living standards - a variant of the developmentalist model of economic modernisation practised in East Asia during that region's period of rapid growth in the 1970s and 1980s [51]. Although semi-authoritarian and authoritarian regimes may have an easier time formulating subsidy reform policies than a democratic India, they are highly cautious about the speed of implementation, and try to synchronise it with economic growth, regime popularity, inflation and real incomes. Regardless of the type of political system, decision makers in all three countries are wary of hasty and harsh subsidy reforms that would greatly increase the burden on much of the population.

Energy protests and resistance have become more frequent in recent years in each of these states. China saw a number of protests in 2008, including one incident when a shortage of diesel in the economically dynamic southeast led to widespread discontent [26]. Also Russia has experienced growing numbers of demonstrations of late, with people protesting mismanagement of the economy, unemployment, rising energy prices and increased duties on imported cars [52-54]. In India, protests over government attempts to raise energy prices have been a familiar occurrence for many years.

An additional constituency that prevents federal policymakers from removing subsidies are the sub-national governments. Provincial governments are responsible for implementing central government policy, but often also set subsidy rates in a number of areas. While provincial governments may be required by law to reduce subsidies, they may circumvent such requirements by indirect means like tax cuts, creative accounting, tax exemptions, quotas or dual exchange rates. In China, farmers, truckers, railroads and shipping companies - highly vocal constituencies campaigning to keep fuel prices down — often find a receptive audience in their sub-national governments [26].

\subsection{Vicious Infrastructural Circles}

The existence of energy subsidies creates a vicious circle in that energy companies saddled with the high subsidies lack the funds necessary to improve the energy infrastructure of their countries. In addition, the underdeveloped energy infrastructure in much of India, China and Russia makes customers unwilling to part with subsidies. Reducing subsidies will increase their bills, while, if this 
money is reinvested in the energy sector, it will take some time for consumers to benefit from improved service. Thus a dilemma exists, and up-front government-funded or guaranteed investment in infrastructure may be the only way to break out of this situation. Once infrastructure has improved, it will be easier to start charging users proper rates.

However, overcoming the existing infrastructure problems will be no easy task, due to the dynamics that often lead to this situation in the first place. The government, short on cash, sees the power sector as a free subsidy vehicle, effectively drawing down on past investments in the sector. But if it lacks sufficient funds to provide direct (non-energy) subsidies to poor people in the first place, it is not likely to spend its own funds to upgrade the power sector so that it can then justify raising power prices to those people. Governments sometimes see privatisation as the answer, but may then still prove reluctant to let the privatised sector charge rates that would cover costs because they continue fearing the reaction of the population even when price hikes are implemented by private actors.

In India, state electricity boards have been bankrupted by the subsidy regime, leaving little money for reinvestment or extension of the grid to the estimated 412 million poor without access to electricity. In 2000/2001, the commercial losses of state electricity boards were about USD 5 billion [38]. Electricity is unavailable for up to 14 hours a day in many parts of the country, which results in many wealthier households and small manufacturers using subsidised and polluting diesel generators [14]. The poor condition of India's energy sector is also reflected in the high transmission and distribution costs. The IEA reports that the combined rate of these in 2005 was 32 percent across India (about 15 percent is due to theft), with some states reporting losses exceeding 50 percent. By contrast, transmission and distribution loss rates in the OECD are approximately 14 percent [14]. Further highlighting the gravity of the challenge, the IEA notes that India will need to invest USD 956 billion in infrastructure over the period to 2030 [14].

China has also experienced numerous power shortages in recent years due to a deficit of generating capacity, coal shortages and an antiquated electricity grid. A March 2007 power shortage effectively highlighted the extent of these problems, when blackouts hit thirteen provinces in central China following heavy snowfall and soaring demand. Severe snowstorms also occurred the following January, causing power shortages which one report noted were exacerbated by a combination of liberalised coal prices and capped electricity prices, straining operating costs for power plants [26,55].

Russia has seen increasing energy demand in recent years, while much of its old generating capacity has been deteriorating. Almost all the country's power plants were installed in the Soviet period and many will reach the end of their lifespan around 2010 [56]. Russia has already had various supply problems with electricity rationing as well as blackouts. A blackout in the spring of 2005 triggered the disconnection of 2,500 megawatts of electricity capacity, affecting four million people-equal to roughly a quarter of Moscow's population. Supply problems have also affected the expansion of the electricity grid, with only 16 percent of new grid connection requests approved in the winter of 2005-2006 [43].

Another issue related to infrastructure is the lack of metering, especially in Russia and India, which translates into wastage. For example, in large Russian housing blocks it is often impossible to adjust the amount of heat to each apartment; customers cannot meter, adjust or even refuse the heat provided [44]. This results in large-scale inefficiencies. Since consumers cannot reduce the heat, they 
simply open windows. People who cannot even regulate how much energy they use will understandably be discontent with higher prices due to subsidy reductions.

\subsection{Playing the Green Card}

The situation is not completely bleak. One strategy for convincing the citizenry of the need for subsidy reform could be its effects on reducing local pollution and thus improving the 'Green GDP' - meaning the GDP of a given state minus costs related to environmental damage, including cleanup and healthcare costs [57]. Only 1 percent of China's 560 million-strong urban population breathe air considered safe by EU standards [18]. If Beijing can convince people that reducing subsidies will directly lead to health benefits, it will face far fewer roadblocks to the implementation of these policies. However, obstacles at the provincial level, such as officials more concerned about personal profits and provincial economic growth than the environment, may persist. A 2007 report noted that, despite Beijing's 2002 directive that sought to limit the number of new coal-burning plants, the north-central province of Ningxia built at least three that either did not have the required permits or failed to live up to new environmental standards [58].

While an important topic on the global political agenda, climate change has not resonated to the same degree with the population or governments of Russia, China and India. Russian scientists and decision makers are sceptical about anthropogenic (human-induced) climate change [59,60], whereas India and China have resisted emissions caps, stressing their right to economic growth and development, and their own relatively low per capita energy consumption. Nonetheless, climate politics in the form of the Kyoto Protocol and potential agreements in the wake of the anticlimactic December 2009 Copenhagen Summit could be used to promote subsidy reductions in these countries on a purely financial basis. Russia could benefit from the implementation of Joint Implementation projects under Kyoto, likewise for China and India under the Clean Development Mechanism. Both could lead to foreign direct investment and job creation. So far neither of these mechanisms are deemed successes, but that could change if the rules surrounding them were simplified and emissions quotas were reduced. Alternatively, new and more effective mechanisms may be established under a post-Kyoto regime. Linking subsidy reduction to increased economic opportunities, foreign direct investment and higher international standing could help to mitigate any social discontent and unrest resulting from the implementation of subsidy reductions.

\subsection{Impact of the Global Recession}

Even in the face of the global economic recession, Beijing and Moscow have thus far been able to afford subsidies - China due to its large budget surpluses and currency reserves, and Russia in its role as one of the world's largest energy exporters. Nevertheless, with a weakened world economy, the question remains whether India, China and Russia will be able to maintain their subsidy regimes. For China, this issue is not as relevant, since the total cost of subsidies as a percentage of GDP is lower and therefore exerts less pressure on China to raise prices soon. Oil subsidies are estimated at about 1 percent of GDP, and the budget surplus and small public debt should enable Beijing to keep prices down for some time [61]. 
For India and Russia, the situation is somewhat more problematic. Russia's economic situation has been deteriorating rapidly, fuelled by the dual problems of the global financial crisis and falling oil prices. Its budget, heavily dependent upon oil revenues, was calculated on the basis of an estimated USD 70 a barrel, yet Urals Crude was trading at USD 47 a barrel in early 2009 [62]. Although it has since risen again, Russia's dependence on high oil prices remains a major liability for the country. Russian energy subsidies, the largest in the world, totalling USD 40 billion in 2005, will prove even harder to finance. Despite Russia's success in increasing electricity and gas prices, the yearly price increases are substantial, and combined with a deteriorating economy may have severe consequences for the Russian population and industry. Thus, although Moscow is reluctant to increase the economic stress on the population in the current situation, it needs to do so more than ever because it has lost a large part of its tax revenue. Although raising prices to international levels should be easier now because oil and gas prices have fallen in conjunction with the financial crisis, the reduced purchasing power of the population will make this harder to carry through.

As for India, economic pressures prompted three fuel price rises between February 2008 and July 2009, but kerosene prices, important for cooking in poorer households, were not affected [63]. Ultimately, the issue for these governments will be to balance the price of continued subsidies, the socio-political 'pain' of a reduced subsidy and the reactions of decision makers to that pain.

\section{Conclusions}

Energy subsidies are a complex subject with many economic, social and political variables involved. There are also limitations on up-to-date data from countries such as China, India and Russia. Nonetheless, these three countries are such an important part of global energy consumption that it is still worth looking at them, and we are able to discern some important patterns. Since the countries and their energy sectors are dissimilar in many respects, the consistency in these patterns may seem paradoxical. Neither the differences in degree of democracy, income level, status as importing or exporting countries or differences between the type of energy used and subsidised seem to have a significant impact on the capacity for subsidy reform in these three countries.

In all three countries, there is discernible political will to proceed with reducing energy subsidies. Because countries such as these represent such a large part of the world's emerging energy consumption, at the global level this will result in major changes in the way energy is priced and used over the medium to long term. This in turn has implications for crude oil demand, for geopolitical competition over energy resources and, not least, for global climate policy. The impact on global climate policy will not come so much from other countries modelling their policies on those of China, India and Russia - they are too different from most countries in the world for that — but rather because the policies of these countries will be an important part of the framework conditions for any future international climate negotiations. If these three are unable to fit new internationally agreed measures into their national policies, countries such as the US are likely to refuse doing so in their own domestic policies, and the possibility of far-reaching climate agreements unravels.

The implementation of subsidy reform is not a straightforward process: although subsidy reform is proceeding, it will take time and will advance in fits and starts. Obstacles to subsidy reform in these countries include: rent-seeking by entrenched interests that benefit from the status quo, incongruence 
between the national and provincial levels of government that encumbers the implementation of reforms, the poor state of infrastructure, and the global economic downturn. Greater political will and better funding will be needed to tackle these challenges and balance the various interests. In particular, it will be necessary for governments to step in financially and resolve the impasse related to infrastructure and quality of service. Only after governments take the initiative to improve infrastructure and service will it be realistic to start increasing prices across the board.

Equally important will be whether governments can effectively convince their populations that reducing subsidies will benefit them directly, since subsidies have failed to achieve their original goals. This in turn will depend on the capacity of the government to turn the profits from reduced subsidies into other welfare goods. Such efforts will require trust between politicians and the people-so democracy may ultimately be the best mechanism for eliminating subsidies. India may in fact possibly have an easier time removing subsidies because its political system is used to dealing with political protests. The more rigid systems of Russia and China, while theoretically better insulated from popular demands and capable of adopting economically rational policies, may prove more politically brittle in dealing with the stresses caused by the phasing out of energy subsidies.

\section{Acknowledgements}

This article was written as part of the RussCasp project, which is financed by the PETROSAM programme of the Norwegian Research Council.

\section{References and Notes}

1. Reforming Energy Subsidies: Opportunities to Contribute to the Climate Change Agenda; Division of Technology, Industry and Economics, United Nations Environmental Programme (UNEP): Geneva, Switzerland, 2008.

2. Russia Energy Profile; Energy Information Administration (EIA): Washington, DC, USA, 2008.

3. World Development Report 2009: Reshaping Economic Geography; Discussion Paper No. 0224; World Bank: Washington, DC, USA, 2009.

4. Diamond, L. Elections without democracy: Thinking about hybrid regimes. J. Democr. 2002, 13, 21-35.

5. Schedler, A. Elections without democracy: The menu of manipulation. J. Democr. 2002, 13, 36-50.

6. Srivastava, D.K.; Rao, C.B.; Chakraborty, P.; Rangamannar, T.S. Budgetary Subsidies in India: Subsidising Social and Economic Services; National Institute of Public Finance and Policy: New Dehli, India, 2003.

7. Alderman, H. Subsidies as a Social Safety Net: Effectiveness and Challenges, Social Protection; World Bank: Washington, DC, USA, 2002.

8. Energy Subsidies in the European Union: A Brief Overview; Technical Report 1; European Environment Agency (EEA): Copenhagen, Denmark, 2004.

9. Shalizi, Z. Energy and Emissions: Local and Global Effects of the Rise of India and China; World Bank Policy Research Working Paper 4209; World Bank: Washington, DC, USA, 2007. 
10. Doggett, T.; Rascoe, A. Global energy demand seen up 44\% by 2030. Reuters, 27 May 2009.

11. Broadman, H.G. China and India go to Africa. Foreign Aff. 2008, 87, 95-109.

12. Mead, R.W.; Brajer V. Environmental cleanup and health gains from Beijing's Green Olympics. Chin. Quart. 2008, 194, 275-293.

13. Downs, E.S. The Chinese energy security debate. Chin. Quart. 2004, 177, 261.

14. World Energy Outlook: China and India Insights; International Energy Agency (IEA): Paris, France, 2007.

15. Adams, F.G.; Shachmurove, Y. Modelling and forecasting energy consumption in China: Implications for Chinese energy demand and imports in 2020. Energ. Econ. 2007, 30, 1263-1278.

16. Sinton, J.; Stern, R.E.; Aden, N.T.; Lin, J.; McKane, A.T.; Price, L.K.; Wiser, R.H.; Zhou, N.; Ku, J.Y. Evaluation of China's Energy Strategy Options; The China Sustainable Energy Program: Berkeley, CA, USA, 2005.

17. Cornelius, P.; Story, J. China and global energy markets. Orbis 2007, 51, 5-20.

18. Kahn, J.; Yardley, J. As China roars, pollution reaches deadly extremes. New York Times, 26 August 2007.

19. Zha, D. China's energy security: Domestic and international issues. Survival 2006, 48, 179-190.

20. Haley, U.C. Shedding light on energy subsidies in China: An analysis of China's steel industry from 2000-2007. In Proceedings of the Alliance for American Manufacturing, Washington, DC, USA, 8 January 2008.

21. World Energy Outlook; International Energy Agency (IEA): Paris, France, 2006.

22. China's Energy Conditions and Policies; White Paper for Information Office of the State Council of the People's Republic of China: Beijing, China, 2007.

23. Ming, Y. China's rural electrification and poverty reduction. Energ. Policy 2003, 31, 283-295.

24. Crompton, P.; Wu, Y. Energy consumption in China: Past trends and future directions. Energ. Econ. 2005, 27, 195-208.

25. Two Chinese provinces move to limit thermal coal prices. Xinhua, 5 June 2008.

26. Collins, G. Over a barrel: China's problems with oil. Jane's Intel. Rev. 2008, March, 54-55.

27. IEA Energy Statistics; International Energy Agency (IEA): Paris, France, 2008.

28. Dyer, G. Beijing moves to overhaul retail fuel prices. Financial Times, 6 December 2008.

29. China to bolster oil reserves. Industry Updates, 2 March 2008.

30. Palmer, D. Huge energy subsidies fuel China steel export. Reuters, 8 January 2008.

31. Dyer, G. Beijing targets aid to soften energy impact. Financial Times, 21 June 2008.

32. China increases prices for oil and electricity. Shanghai Daily, 20 June 2008.

33. China should stop energy subsidies - Central Bank chief. Reuters, 16 September 2008.

34. Chen, E.; Verma, N. In China, India, higher fuel prices not yet high enough. Guardian/Reuters, 2 July 2009.

35. Liu, J. China's latest fuel price rise triggers public debate. Xinhua, 1 July 2009.

36. International Energy Statistics; Energy Information Administration (EIA): Washington, DC, USA, 2009.

37. Ailawadi, V.S.; Bhattacharyya, S.C. Access to energy services by the poor in India: Current situation and the need for alternative strategies. Natl. Resour. Forum 2006, 30, 2-14. 
38. Kale, S. Current reforms: the politics of policy change in India's electricity sector. Pac. Aff. 2004, 77, 467-491.

39. Pachauri, S.; Jiang, L. The household energy transition in India and China. Energ. Policy 2008, 36, 4022-4035.

40. Morgan, T. Electricity subsidies in India. In Energy Subsidies: Lessons Learned in Assessing Their Impact and Designing Policy Reforms; von Moltke, A., McKee, C., Morgan, T., Eds.; United Nations Environment Programme (UNEP): New York, NY, USA, 2004.

41. Economic Survey 2008-2009; Ministry of Finance of India: New Delhi, India, 2009.

42. Ahrend, R.; Thomson, W. Unnatural monopoly: The endless wait for gas sector reform in Russia. Europe-Asia Stud. 2005, 57, 801-821.

43. Energy Efficiency in Russia: Untapped Reserves; Report No. 46936; World Bank: Washington, DC, USA, 2008.

44. Bashmakov, I. Energy Subsidies in Russia: The Case of District Heating; Russian Centre for Energy Efficiency: Moscow, Russia, (unpublished book manuscript).

45. Øverland, I.; Dansie, G.; Kjærnet, H. Russian Energy Research and Innovation; Norwegian Institute of International Affairs: Oslo, Norway, 2008.

46. Pittman, R. Restructuring the Russian electricity sector: Re-creating California? Energ. Policy 2007, 35, 1872-1883.

47. Wengle, S. Power politics: Electricity sector reforms in post-Soviet Russia. Russ. Anal. Dig. 2007, 27, 6-9.

48. Liuhto, K. Strategic sectors of the Russian economy: Implications for developing new Northern Dimension partnerships. In The New Northern Dimension of the European Neighbourhood; Blakkisrud, H., Aalto, P., Smith, H., Eds.; Centre for European Policy Studies: Brussels, Belgium, 2009; pp. 180-202.

49. Russian Federation, Regular Review of Energy Efficiency Policies 2007, Energy Charter Protocol on Energy Efficiency and Related Environmental Aspects; Energy Charter: Brussels, Belgium, 2007.

50. Russian Electricity Reform: Emerging Challenges and Opportunities; International Energy Agency (IEA): Paris, France, 2005.

51. Radice, H. The developmental state under global Neoliberalism. Third World Q. 2008, 29, 1153-1174.

52. Grontmakher, Y. Pikalevo as a fuse. Johnson's Russ. List 2009, 107.

53. Petrov, N. Pikalyovo 2009. Moscow Times, 11 June 2009.

54. Zarakhovich, Y. Putin's power vertical doesn't leave other ties to keep Russia together. Jamestown Eurasia Daily Monitor, 25 February 2009.

55. Power blackouts highlight need for pricing system reforms. Shanghai Daily, 31 January 2008.

56. Kurronen, S. Russian electricity sector-reform and prospects. BOFIT Online 2006, 6, 13.

57. Talberth, J.; Bohara, A.K. Economic openness and green GDP. Ecol. Econ. 2006, 58, 743-758.

58. French, H. Far from Beijing's reach, officials bend energy rules. New York Times, 24 November 2007.

59. Moe, A.; Tangen, K. The Kyoto Mechanisms and Russian Gas: A Powerful Combination? Fridtjof Nansen Institute: Oslo, Norway, 1999. 
60. Rowe, E.W. Who is to blame? Agency, causality, responsibility and the role of experts in Russian framings of global climate change. Europe-Asia Stud. 2009, 61, 593-619.

61. Gu, W. China's fuel subsidy costs the world. Reuters, 4 June 2008.

62. Urals crude price averaged $\$ 47$ in January-May. Russian Information Agency Novosti, 1 June 2009.

63. India hikes petrol, diesel prices. Agence France-Presse, 1 July 2009.

(C) 2010 by the authors; licensee Molecular Diversity Preservation International, Basel, Switzerland. This article is an open-access article distributed under the terms and conditions of the Creative Commons Attribution license (http://creativecommons.org/licenses/by/3.0/). 